\title{
Synthesis of boronated phenylalanine analogues with a quaternary center for boron neutron capture therapy
}

\author{
Marek Zaidlewicz*, Joanna Cytarska, Adam Dzielendziak, and Marta Ziegler-Borowska \\ Department of Chemistry, Nicolaus Copernicus University, 87-100 Torun, Polan \\ E-mail:zaidlevi@,chem.uni.torun.pl
}

Dedicated to Professor Mieczyslaw Makosza on the occasion his $7^{\text {th }}$ birthday

(received 01 Aug 03; accepted 29 Sept 03; published on the web 02 Oct 03)

\begin{abstract}
2-Amino-2-methyl-3-(4-dihydroxyborylphenyl)propionic acid (3, $\alpha$-methyl-BPA) and 1-amino3-(4-dihydroxyborylbenzyl)cyclobutanecarboxylic acid 4, which are (4-dihydroxyborylphenyl)alanine (BPA) analogues containing a quaternary center, have been synthesized from 4-allylbromobenzene. $\alpha$-Methyl-BPA has also been prepared from D,L-alanine, and the route is suitable for the synthesis of $\alpha$-alkyl-BPA. Both $\mathbf{3}$ and $\mathbf{4}$ exhibit very similar $\mathrm{R}_{\mathrm{f}}$ values indicating similar lipophilicities. The products have been prepared as potential boron carriers for Boron Neutron Capture Therapy.
\end{abstract}

Keywords: Boronic acids, boronated amino acids

\section{Introduction}

Boron Neutron Capture Therapy (BNCT) is a binary therapy requiring selective accumulation of boron-10 in a tumor cell. Irradiation of such cells by thermal neutrons results in a nuclear reaction producing an $\alpha$-particle and lithium-7 ion of high energy destroying the cell. ${ }^{1-6}$ Early studies revealed that selective accumulation of boron in a tumor cell and low levels of boron in the blood are crucial factors for the therapy. Consequently, over the years several classes of compounds have been examinated as potential boron carriers for BNCT. These include amino acids, antibodies, antisense agents, carbohydrates, growth factors, liposomes, nucleosides, polyamines, porphyrins and thiols, often carrying higher borane or carborane cages to transport a sufficient amount of boron to a tumor cell. ${ }^{1-3,7-10}$ Two compounds, (4-dihydroxyborylphenyl)alanine (BPA, 1) and sodium mercaptoundecahydrododecaborate (BSH, 2) have emerged from these studies, and are used in clinical practice. ${ }^{1-7}$ At present, there is much interest in developing new efficient methods for the preparation of BPA. ${ }^{11-14}$ Although it is a simple boronated amino acid, containing only one boron atom per molecule, it achieves concentrations of boron in a 
tumor cell sufficient for the therapy. However, BPA and BSH are not ideal, since higher concentrations of boron are desirable. Consequently, the synthesis of BPA analogues, including boronated natural and unnatural amino acids and amino alcohols, is the subject of active research. ${ }^{15-21}$ Recently, it was shown that amino acids, such as 1-aminocycloalkanoic acids, cross the blood brain barrier and localize in Glioblastoma Multiforme and metastatic malignant melanoma more avidly than BPA. ${ }^{22}$ This observation prompted a search for BPA analogues and other boronic acids containing 1-aminocycloalkanecarboxylic acid moiety. ${ }^{17-21}$ Such boronated cyclic amino acids contain a quaternary carbon atom bonded to the amino acid functionality. It seemed interesting to compare the effect of such quaternary center incorporated in an acyclic moiety of BPA analogue with a representative cycloalkyl analogue as potential boron carriers for BNCT. Consequently, we decided to prepare 2-amino-2-methyl-3-(4-dihydroxyborylphenyl)propionic acid (3, $\alpha$-methyl-BPA), the simplest BPA analogue containing a quaternary center, and for comparison its cycloalkyl analogue, 1-amino-3-(4-dihydroxyborylbenzyl)cyclobutanecarboxylic acid 4, (Figure 1).

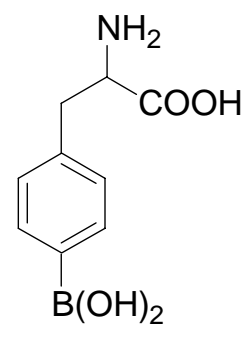

1

BPA

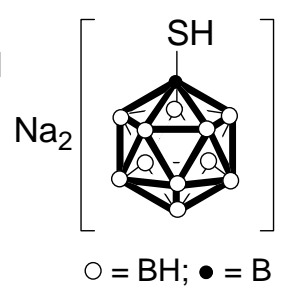

2

$\mathrm{BSH}$

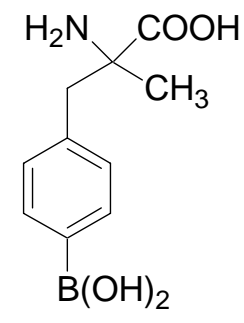

3

$\alpha$-methyl-BPA

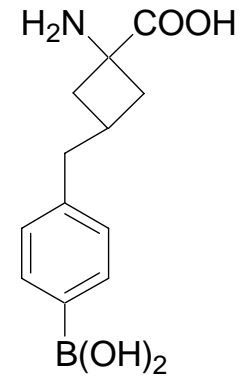

4

\section{Figure 1}

\section{Results and Discussion}

$\alpha$-Methyl-BPA was prepared following two routes, from 4-allylbromobenzene 6 via hydantoin, and from D,L-alanine by deprotonation-benzylation. 1-(4-Bromophenyl)propan-2-one 9, a convenient intermediate for the first route, was prepared starting from 1,4-dibromobenzene $\mathbf{5}$ in an overall $70 \%$ yield and $>99 \%$ purity. Lower yield than might be expected results from competing formation of 1,4-diallylbenzene 7 in the first step, leading to a mixture of 5-7. To suppress the formation of 7, 4-bromophenylmagnesium bromide was prepared from $\mathbf{5}$ by the addition of reagents in a reversed order, and the amount of 7 decreased to 10-15\%. Both products have very close boiling points and their separation by distillation is inconvenient. Consequently, a mixture of 6 and 7, 86:14, was used for the oxymercuration-demercuration reaction. The

product alcohol $\mathbf{8}$ was cleanly separated from the product diol by distillation, and was oxidized 
with PCC to give 9 of $>99 \%$ purity, (Scheme 1). Its ketalization followed by lithiation and transmetallation with triisopropoxyborane gave 1-(4-dihydroxyborylphenyl)propan-2-one 11. Hydantoin 12, readily formed under standard conditions by treatment of $\mathbf{1 1}$ with potassium cyanide and ammonium carbonate, crystallized with one molecule of water per two hydantoin molecules. Alkaline hydrolysis of $\mathbf{1 2}$ under carefully controlled conditions produced $\mathbf{3}$, isolated in $68 \%$ yield. The hydrolysis conditions must be controlled since at lower temperature the reaction is not completed, whereas at higher temperatures deboronated products are formed.
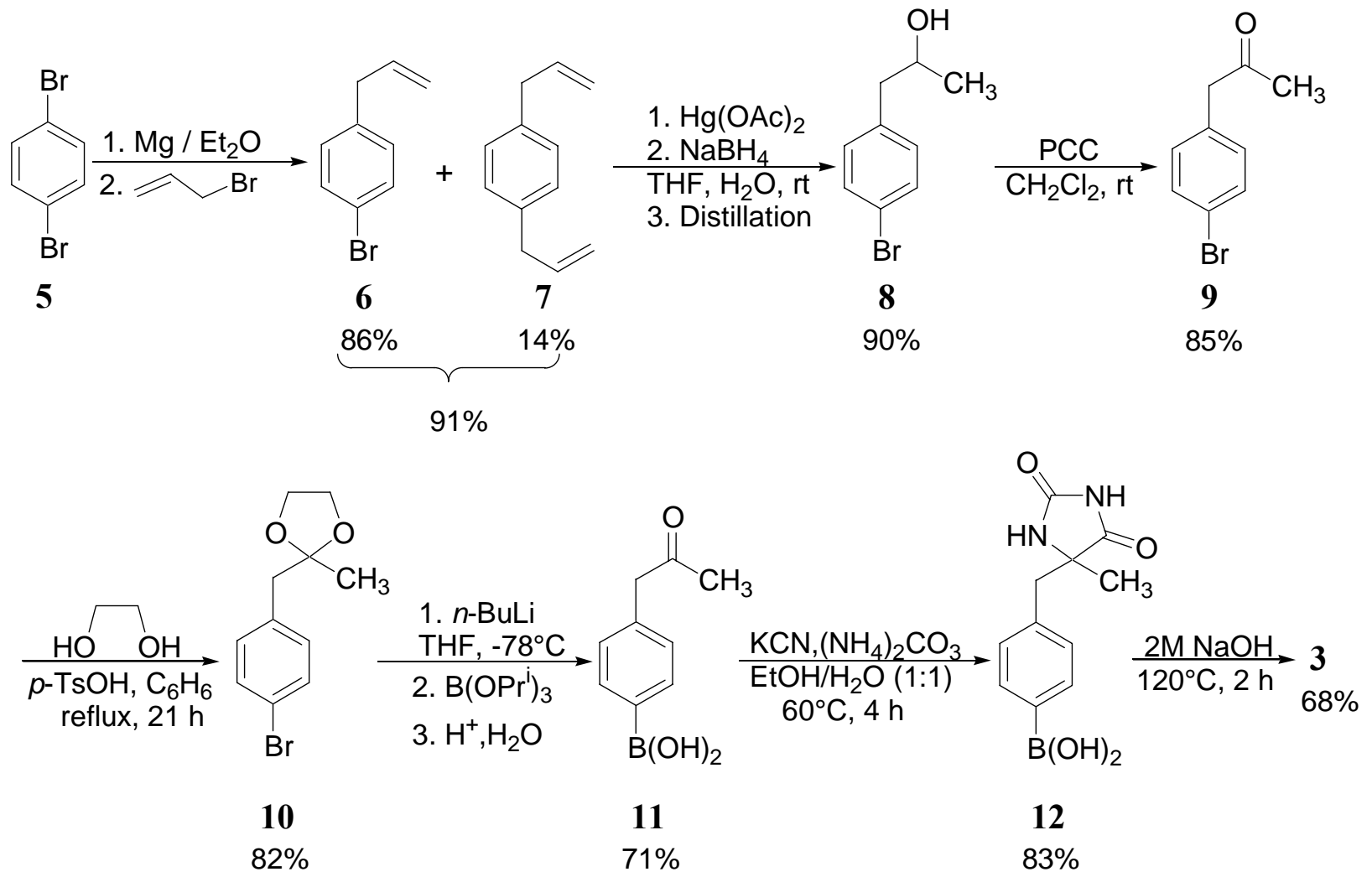

\section{Scheme 1}

The second route to $\mathbf{3}$ required 4-bromomethylphenylboronic acid and D,L-alanine properly protected for the deprotonation step. Based on the literature reports, ${ }^{23,24} 4$-chlorobenz-aldehyde was used to protect the amino group of D,L-alanine, and the carboxylic group was protected as a methyl or ethyl ester. Free radical bromination of $p$-tolylboronic acid 13 produced 4chlorobenzaldehyde acid, however, dibromination was a competing reaction. The crude product was a mixture of 13, mono- and dibrominated acids, its composition depending on the bromine/13 ratio used. The starting acid could be separated by crystallization, however, the solubility of dibrominated acid in several solvents tried was lower than 4-bromomethylphenylboronic acid, and crystallization was not effective for purification. To circumvent the difficulty, $\mathbf{1 3}$ was esterified with ethylene glycol. Although bromination of the ester $\mathbf{1 4}$ gave also 
a mixture of the unreacted starting ester, mono- and dibrominated esters, the monobrominated ester $\mathbf{1 5}$ of $\geq 95 \%$ purity was separated by vacuum distillation, and was used for the reaction with the carbanion generated by deprotonation of protected D,L-alanine with potassium bis(trimethylsilyl)amide (KHMDS). Treatment of the product 16 with $1 \mathrm{M}$ hydrochloric acid deprotected the amino and boronic acid groups to give 17. Deprotection of the methyl ester required reflux with $6 \mathrm{M}$ hydrochloric acid. When ethyl ester was used deprotonation required refluxing for a longer time and the yield of $\mathbf{3}$ was lower.<smiles>Cc1ccc([Ge]O)cc1[C@H](O)CO</smiles>

13<smiles>Cc1ccc(B2OCCO2)c(Br)c1</smiles>

14

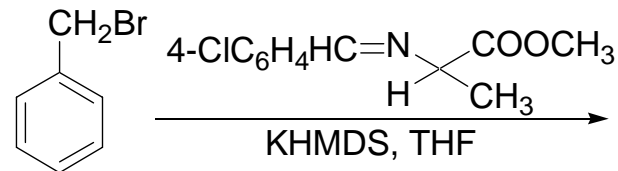

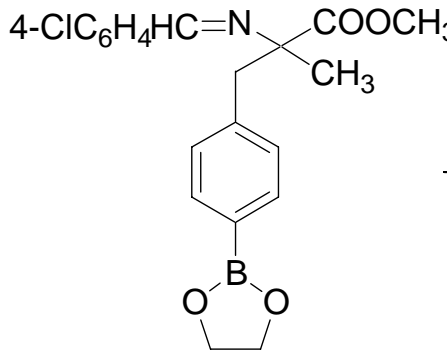

16

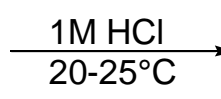<smiles>CB1OCCO1</smiles>

15

$84 \%$

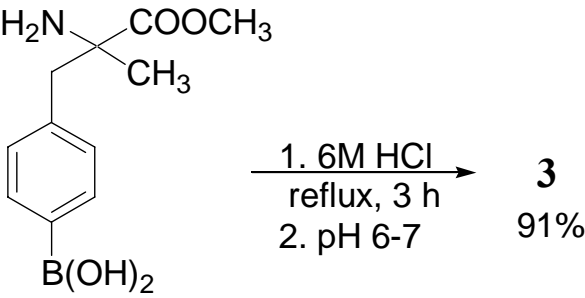

17

93\%

\section{Scheme 2}

The cyclobutyl analogue 4 of BPA was prepared starting from $\mathbf{6}$ via hydantoin 22 (Scheme 3 ), following the route recently used for the synthesis of such cyclobutyl analogues. ${ }^{17}$ The addition of dichloroketene to $\mathbf{6}$ gave $\mathbf{1 8}$ which was reduced without isolation to 3-(4-bromobenzyl)cyclobutanone 19. Lithiation of its ketal 20 and transmetallation with triisopropoxyborane followed by hydrolysis afforded 3-(4-dihydroxyborylbenzyl)cyclobutanone 21. The ketone was transformed into the corresponding hydantoin $\mathbf{2 2}$ which crystallized with one molecule of water. ${ }^{1} \mathrm{H}$ and ${ }^{13} \mathrm{C}$ analysis showed a mixture of diastereomers. The mixture was hydrolyzed under carefully controlled conditions to give $\mathbf{4}$, isolated by crystallization as a mixture of diastereomers. 


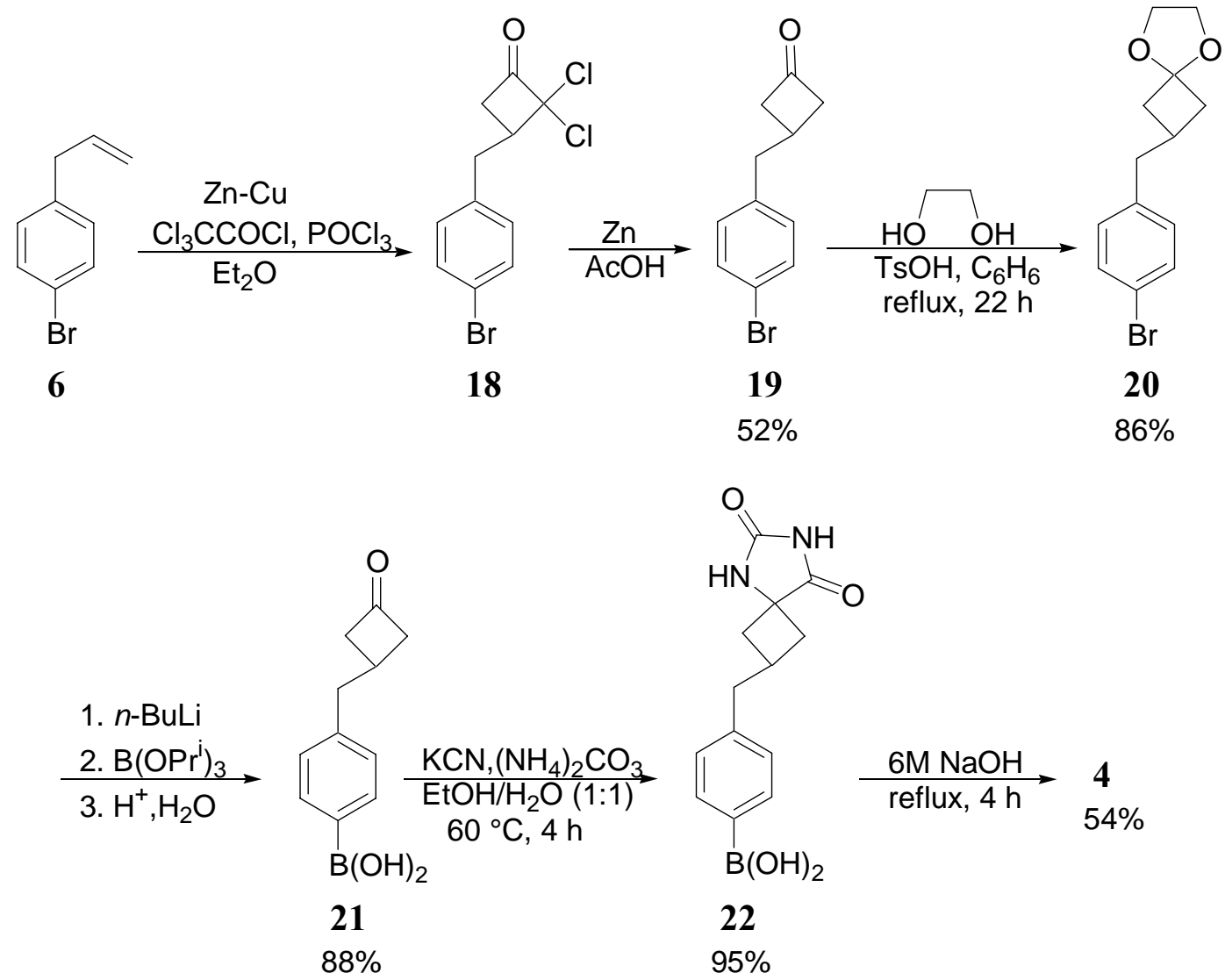

\section{Scheme 3}

The above described boronated amino acids $\mathbf{3}$ and $\mathbf{4}$ exhibited very similar $\mathrm{R}_{\mathrm{f}}$ values, 0.29 and 0.31 , respectively, using as a mobile phase acetonitrile-methanol-water, 10:2:1.5. The result reflects a similar lipophilicity of $\mathbf{3}$ and $\mathbf{4}$, and indicates that the methyl substituted quaternary center of $\mathbf{3}$ and the cyclobutyl ring of $\mathbf{4}$ have a similar effect. The compounds will be tested for BNCT. Lipophilicity of $\alpha$-alkyl-BPA can be controlled by the size of alkyl groups, and the compounds can be readily prepared by monoalkylation of glycine followed by the route shown in Scheme 2. The formation of diastereomers, observed for cycloalkyl analogues, is avoided since only one stereogenic center is present, and the synthesis can be modified to achieve enantioselectivity. Work on the synthesis of $\alpha$-alkyl-BPA is in progress.

\section{Experimental Section}

General Procedures. ${ }^{1} \mathrm{H}$ and ${ }^{13} \mathrm{C}$ NMR spectra were recorded on a Varian Gemini $200 \mathrm{MHz}$, a Bruker AMX $300 \mathrm{MHz}$ and a Varian Inova $500 \mathrm{MHz}$ spectrometers. ${ }^{11} \mathrm{~B}$ NMR spectra were recorded on the Varian Gemini 200 instrument. IR spectra were recorded on a FT-IR Spektrum 2000 Perkin Elmer spectrometer. Microanalyses were performed by the Microanalyses 
Laboratory, Institute of Organic Chemistry PAN, Warsaw. GC analyses were performed on a Hewlett Packard 5890 chromatograph equipped with a $30 \mathrm{~m} \times 0.32 \mathrm{~mm}$ SPB-5 column, a 50 $\mathrm{m} \times 0.32 \mathrm{~mm}$ Carbowax 20M column, and a $5 \mathrm{~m} \times 0.53 \mathrm{~mm}$ HP-1 column. All glassware used for reactions with air sensitive compounds was dried at $150{ }^{\circ} \mathrm{C}$ for several hours, assembled hot, and cooled in a stream of nitrogen. Melting points were measured on a Boetius ESP4/SI, Carl Zeiss Jena, apparatus and are uncorrected. $\mathrm{R}_{\mathrm{f}}$ values were determined using a horizontal TLC chamber and TLC plates Macherey-Nagel Polygram ${ }^{\circledR}$ SIL G/UV ${ }_{254}, 0.20$ mm layer.

Materials. A mixture of 4-allylbromobenzene (6) and 1,4-diallylbenzene (7), 86:14, was prepared from 1,4-dibromobenzene (5) by the literature procedure, ${ }^{25}$ using reversed order of the addition of reagents in the preparation of 4-bromophenylmagnesium bromide. Methyl 2-[(4chlorobenzylidene)amino]propionate was prepared from D,L-alanine methyl ester and 4-chlorobenzaldehyde. ${ }^{24}$ 2-(4-Bromomethylphenyl)-[1,3,2]dioxaborolane (15) was prepared by bromination of 2-(4-tolyl)-[1,3,2]dioxaborolane (14). ${ }^{26}$ Tetrahydrofuran was distilled from benzophenone ketyl prior to use. Diethyl eter and benzene were distilled from lithium tetrahydridoaluminate and were kept under nitrogen.

1-(4-Bromophenyl)propan-2-ol (8). Tetrahydrofuran (200 mL) was added to a stirred solution of mercury(II) acetate (76.48 g, $240 \mathrm{mmol})$ in water $(200 \mathrm{~mL})$. The yellow mixture was stirred for $15 \mathrm{~min}$ and a mixture of 6 and 7 (45.83 g, $200 \mathrm{mmol}$ of $\mathbf{6})$ was added dropwise at room temperature. A clear colorless solution was formed. A 3M sodium hydroxide (200 mL, $600 \mathrm{mmol}$ ) was added followed with a solution of sodium borohydride (5.67 g, $150 \mathrm{mmol})$ in 3M sodium hydroxide $(200 \mathrm{~mL})$ at $20-25^{\circ} \mathrm{C}$. After stirring for $3 \mathrm{~h}$ at room temperature, mercury was separated, and the mixture was saturated with sodium chloride. The organic layer was separated and the aqueous layer was extracted with diethyl ether $(3 \times 50 \mathrm{~mL})$. The extracts were combined with the organic layer, washed with saturated brine $(2 \times 25 \mathrm{~mL})$, dried with anhydrous potassium carbonate and finally with anhydrous magnesium sulfate. The product was isolated by distillation, 38.66 g, 90\%, bp 93-95 ${ }^{\circ} \mathrm{C} / 0.3 \mathrm{mmHg}$. Lit. ${ }^{27}$ bp $106^{\circ} \mathrm{C} / 0.7 \mathrm{mmHg}$. NMR data: $\delta_{\mathrm{H}}$ $\left(200 \mathrm{MHz}, \mathrm{CDCl}_{3}\right) 1.22$ (d, $\left.J=6.0 \mathrm{~Hz}, 3 \mathrm{H}, \mathrm{CH}_{3}\right), 1.65$ (s, 1H, OH), 2.64 (dd, $J=13.6 \mathrm{~Hz}, J=$ $5.4 \mathrm{~Hz}, 1 \mathrm{H}, \mathrm{CH}_{2}$ ), 2.73 (dd, $J=13.6 \mathrm{~Hz}, J=7.6 \mathrm{~Hz}, 1 \mathrm{H}, \mathrm{CH}_{2}$ ), 3.83 (sextet, $J=6.2 \mathrm{~Hz}, 1 \mathrm{H}, \mathrm{CH}$ ), 7.08 (d, $\left.J=8.4 \mathrm{~Hz}, 2 \mathrm{H}, \mathrm{H}_{\mathrm{Ar}}\right), 7.42\left(\mathrm{~d}, J=8.4 \mathrm{~Hz}, 2 \mathrm{H}, \mathrm{H}_{\mathrm{Ar}}\right) . \delta_{\mathrm{C}}\left(\mathrm{CDCl}_{3}\right) 22.82\left(\mathrm{CH}_{3}\right), 44.99$ $\left(\mathrm{CH}_{2}\right), 68.59(\mathrm{C}-\mathrm{O}), 120.29(\mathrm{C}), 131.08(\mathrm{CH}), 131.50(\mathrm{CH}), 137.50(\mathrm{C})$. IR (film) cm $\mathrm{cm}^{-1}: 3360$ (sb, OH), 1070 (s, C-O), 820 (m, $\mathrm{CH}_{\mathrm{Ar}}$ ), 790 (s, $\mathrm{CH}_{\mathrm{Ar}}$ ).

1-(4-Bromophenyl)propan-2-one (9). Pyridinium chlorochromate (32.33 g, $150 \mathrm{mmol}$ ) was added in portions to a stirred solution of 8 (21.51 g, $100 \mathrm{mmol})$ in methylene chloride (300 $\mathrm{mL}$ ) at $20-25^{\circ} \mathrm{C}$. The mixture was stirred for $4 \mathrm{~h}$ and diethyl ether $(300 \mathrm{~mL})$ was added. The solution was decanted from precipitated chromium salts and filtrated through a silica gel pad (30 g) which was then washed with diethyl ether $(50 \mathrm{~mL})$. The product was isolated by distillation, $18.11 \mathrm{~g}$, $85 \%$, bp $80-81^{\circ} \mathrm{C} / 0.2 \mathrm{mmHg}$, mp $24-25^{\circ} \mathrm{C}$. Lit. ${ }^{28}$ bp $139^{\circ} \mathrm{C} / 11 \mathrm{mmHg}$. 
NMR data: $\delta_{\mathrm{H}}\left(200 \mathrm{MHz}, \mathrm{CDCl}_{3}\right) 2.17\left(\mathrm{~s}, 3 \mathrm{H}, \mathrm{CH}_{3}\right), 3.66\left(\mathrm{~s}, 2 \mathrm{H}, \mathrm{CH}_{2}\right), 7.07$ and $7.46(4 \mathrm{H}$, an AA'XX' system of para disubstituted benzene). $\delta_{\mathrm{C}}\left(\mathrm{CDCl}_{3}\right) 29.32\left(\mathrm{CH}_{3}\right), 50.01\left(\mathrm{CH}_{2}\right), 121.02$ (C), $131.08(2 \times \mathrm{CH}), 131.73(2 \times \mathrm{CH}), 133.07(\mathrm{C}), 205.34(\mathrm{C}=\mathrm{O})$.

1-(4-Bromophenyl)propan-2-one ethylene ketal (10). A mixture of 9 (14.82 g, $70.0 \mathrm{mmol})$, ethylene glycol (18.6 mL, $300 \mathrm{mmol})$, p-toluenesulfonic acid (0.60 g, $3 \mathrm{mmol}$ ), and benzene (220 mL) was refluxed with a Dean-Stark trap for $21 \mathrm{~h}$, and water $(1.3 \mathrm{~mL})$ was collected. The mixture was washed with $3 \mathrm{M}$ sodium hydroxide $(5 \mathrm{~mL})$, water $(50 \mathrm{~mL})$, and dried with magnesium sulfate. The product was isolated by distillation, $14.82 \mathrm{~g}, 82 \%$, bp $89-90^{\circ} \mathrm{C} / 1 \mathrm{mmHg}$. NMR data: $\delta_{\mathrm{H}}\left(200 \mathrm{MHz}, \mathrm{CDCl}_{3}\right) 1.30$ (s, 3H, $\left.\mathrm{CH}_{3}\right), 2.87\left(\mathrm{~s}, 2 \mathrm{H}, \mathrm{CH}_{2}\right), 3.81\left(\mathrm{~m}, 4 \mathrm{H}, \mathrm{CH}_{2}\right.$, an AA'BB' system with 18 lines symmetrically placed about the center), 7.15 (d, $J=8.6 \mathrm{~Hz}, 2 \mathrm{H}$, $\left.\mathrm{H}_{\mathrm{Ar}}\right), 7.40$ (d, $\left.J=8.6 \mathrm{~Hz}, 2 \mathrm{H}, \mathrm{H}_{\mathrm{Ar}}\right) . \delta_{\mathrm{C}}\left(\mathrm{CDCl}_{3}\right) 24.44\left(\mathrm{CH}_{3}\right), 44.76\left(\mathrm{CH}_{2}\right), 64.88\left(2 \times \mathrm{CH}_{2}\right)$, 109.37 (C), 120.45 (C), 131.01 (2 × CH), 132.27 (2 × CH), 135.91 (C).

1-(4-Dihydroxyborylphenyl)propan-2-one (11). A $2.36 \mathrm{M}$ solution of $n$-butyllithium in hexanes (23.3 mL, $55.0 \mathrm{mmol}$ ) was added dropwise with stirring to a solution of $\mathbf{1 0}$ (12.90 g, $50.0 \mathrm{mmol}$ ) in tetrahydrofuran $(150 \mathrm{~mL})$ at $-78^{\circ} \mathrm{C}$ under argon atmosphere, and the mixture was stirred for $2 \mathrm{~h}$ at this temperature. Triisopropoxyborane $(12 \mathrm{~mL}, 51.0 \mathrm{mmol})$ was added dropwise and the mixture was left for $24 \mathrm{~h}$ at room temperature. It was cooled to $0^{\circ} \mathrm{C}, 2 \mathrm{M}$ hydrochloric acid (75 mL, $150 \mathrm{mmol}$ ) was added, and the mixture was stirred for $24 \mathrm{~h}$ at room temperature. The organic layer was separated and the aqueous layer was extracted with diethyl ether $(3 \times 10 \mathrm{~mL})$. Solvents were removed and the remaining oil was dissolved in $2 \mathrm{M}$ sodium hydroxide, the solution was extracted with diethyl ether $(2 \times 50 \mathrm{~mL})$, acidified with $3 \mathrm{M}$ hydrochloric acid, extracted with diethyl ether $(3 \times 50 \mathrm{~mL})$ and the extract was washed with saturated brine $(20 \mathrm{~mL})$. Ether was removed and the product was obtained as a grey-white solid which was crystallized from ethyl acetate, $6.32 \mathrm{~g}, 71 \%$, mp 195-196 ${ }^{\circ} \mathrm{C}$. NMR data: $\delta_{\mathrm{H}}\left(200 \mathrm{MHz}, \mathrm{CDCl}_{3}\right)$ 2.20 (s, 3H, $\mathrm{CH}_{3}$ ), 3.80 (s, 2H, $\mathrm{CH}_{2}$ ), 7.38 (d, $J=10.0 \mathrm{~Hz}, 2 \mathrm{H}, \mathrm{H}_{\mathrm{Ar}}$ ), 8.20 (d, $J=10.0 \mathrm{~Hz}, 2 \mathrm{H}$, $\left.\mathrm{H}_{\mathrm{Ar}}\right) . \delta_{\mathrm{C}}\left(\mathrm{CDCl}_{3}\right) 29.39\left(\mathrm{CH}_{3}\right), 51.26\left(\mathrm{CH}_{2}\right), 129.11(2 \times \mathrm{CH}), 136.07(2 \times \mathrm{CH}), 138.95(\mathrm{C})$, $205.81(\mathrm{C}=\mathrm{O}) . \delta_{\mathrm{B}}\left(\mathrm{CDCl}_{3}\right) 30.63$.

1-(4-Dihydroxyborylphenyl)propan-2-one hydantoin (12). A mixture of 11 (2.67 g, $15.0 \mathrm{mmol}), 50 \%$ aqueous ethanol $(45 \mathrm{~mL})$, potassium cyanide (1.95 g, $30.0 \mathrm{mmol})$, and ammonium carbonate $(6.82 \mathrm{~g}, 80.0 \mathrm{mmol})$ was placed in an autoclave and kept at $60^{\circ} \mathrm{C}$ for $4 \mathrm{~h}$. The mixture was acidified with 6M hydrochloric acid, and filtered through a pad of activated carbon. Solvents were removed by evaporation at room temperature, and the solid material which remained was extracted with diethyl ether in a Soxlet apparatus. A pale beige small crystals precipitated from the concentrated solution, $3.20 \mathrm{~g}, 83 \%$, mp $211-215^{\circ} \mathrm{C}$.

Anal. Calcd. for $\mathrm{C}_{11} \mathrm{H}_{13} \mathrm{BN}_{2} \mathrm{O}_{4} \cdot 0.5 \mathrm{H}_{2} \mathrm{O}$ (257.05): C, 51.39; H, 5.49; N, 10.90. Found: C, 51.38; H, 5.48; N, 10.56. NMR data: $\delta_{\mathrm{H}}\left(200 \mathrm{MHz}\right.$, acetone- $\left.\mathrm{d}_{6}\right) 1.50\left(\mathrm{~s}, 3 \mathrm{H}, \mathrm{CH}_{3}\right), 2.91(\mathrm{~d}, J=13.0 \mathrm{~Hz}$, $1 \mathrm{H}, \mathrm{CH}_{2}$ ), 3.11 (d, $J=13.0 \mathrm{~Hz}, 1 \mathrm{H}, \mathrm{CH}_{2}$ ), 7.04 (s, $\left.1 \mathrm{H}, \mathrm{NH}\right), 7.22$ (d, $J=8.0 \mathrm{~Hz}, 2 \mathrm{H}, \mathrm{H}_{\mathrm{Ar}}$ ), 7.78 $\left(\mathrm{d}, J=8.0 \mathrm{~Hz}, 2 \mathrm{H}, \mathrm{H}_{\mathrm{Ar}}\right), 9.24(\mathrm{~s}, 1 \mathrm{H}, \mathrm{NH}) . \delta_{\mathrm{C}}\left(\right.$ acetone- $\left._{6}\right) 23.73\left(\mathrm{CH}_{3}\right), 43.48\left(\mathrm{CH}_{2}\right), 63.86(\mathrm{C})$, $129.62(2 \times \mathrm{CH}), 134.10(2 \times \mathrm{CH}), 137.85(\mathrm{C}), 155.76(\mathrm{C}=\mathrm{O}), 177.32(\mathrm{C}=\mathrm{O}) . \delta_{\mathrm{B}}\left(\right.$ acetone- $\left.\mathrm{d}_{6}\right)$ 33.96. 


\section{2-Amino-3-(4-dihydroxyborylphenyl)-2-methylpropionic acid (3)}

By hydrolysis of 12. A mixture of $12(0.80 \mathrm{~g}, 3.3 \mathrm{mmol})$ and a $2 \mathrm{M}$ sodium hydroxide solution (33 mL, $16.5 \mathrm{mmol}$ ) was placed in an autoclave and kept at $120^{\circ} \mathrm{C}$ for $2 \mathrm{~h}$. After cooling, the mixture was treated with $4 \mathrm{M}$ hydrochloric acid to $\mathrm{pH}$ 6.5-7. The precipitated gelatinous solid was filtered off and washed with warm water $(25 \mathrm{~mL})$. The filtrate was concentrated under vacuum and the product crystallized out. Recrystallization from water gave $0.49 \mathrm{~g}$, 68\% pale beige crystals, mp 302-305 ${ }^{\circ} \mathrm{C}$ (decomposition). NMR data: $\delta_{\mathrm{H}}\left(200 \mathrm{MHz}, \mathrm{D}_{2} \mathrm{O} / \mathrm{NaOD}\right) 1.38$ (s, $3 \mathrm{H}, \mathrm{CH}_{3}$ ), 2.78 (d, $J=14.1 \mathrm{~Hz}, 1 \mathrm{H}, \mathrm{CH}_{2}$ ), 3.12 (d, $\left.J=14.1 \mathrm{~Hz}, 1 \mathrm{H}, \mathrm{CH}_{2}\right), 7.04$ (d, $J=7.8 \mathrm{~Hz}$, $\left.2 \mathrm{H}, \mathrm{H}_{\mathrm{Ar}}\right), 7.45\left(\mathrm{~d}, J=7.8 \mathrm{~Hz}, 2 \mathrm{H}, \mathrm{H}_{\mathrm{Ar}}\right) . \delta_{\mathrm{C}}\left(\mathrm{D}_{2} \mathrm{O} / \mathrm{NaOD}\right) 24.76\left(\mathrm{CH}_{3}\right), 44.92\left(\mathrm{CH}_{2}\right), 62.06(\mathrm{C})$, $129.86(2 \times \mathrm{CH}), 132.74(2 \times \mathrm{CH}), 134.27(\mathrm{C}), 180.56(\mathrm{C}=\mathrm{O}) . \delta_{\mathrm{B}}\left(\mathrm{D}_{2} \mathrm{O} / \mathrm{NaOD}\right) 4.49$.

From D,L-alanine. A solution of potassium bis(trimethylsilyl)amide (4.40 g, $21.0 \mathrm{mmol})$ in tetrahydrofuran $(15 \mathrm{~mL})$ was added dropwise with stirring to a solution of methyl 2-[(4chlorobenzylidene)amino]propionate $(4.80 \mathrm{~g}, 20.0 \mathrm{mmol})$ in tetrahydrofuran $(20 \mathrm{~mL})$ at $-78^{\circ} \mathrm{C}$, and the red-brown mixture was stirred for $15 \mathrm{~min}$. A solution of 15 (4.82 g, $20.0 \mathrm{mmol}$ ) in tetrahydrofuran $(20 \mathrm{~mL})$ was added to the mixture at $-78^{\circ} \mathrm{C}$, stirring was continued for $3 \mathrm{~h}$, and the mixture was allowed to warm to $-10^{\circ} \mathrm{C}$. Hydrochloric acid ( $60 \mathrm{~mL}, 60.0 \mathrm{mmol}$ ) was added below $0^{\circ} \mathrm{C}$ and the mixture was stirred overnight at room temperature. The mixture was alkalized with $3 \mathrm{M}$ sodium hydroxide solution, and extracted with diethyl ether $(2 \times 50 \mathrm{~mL})$. The aqueous layer was separated, acidified with $2 \mathrm{M}$ hydrochloric acid to $\mathrm{pH}$ 6.5-7.0, concentrated under vacuum, 6M hydrochloric acid (100 mL, $0.60 \mathrm{~mol})$ was added, and the mixture was refluxed for 3 h. Hydrochloric acid was removed under vacuum at room temperature. The product was

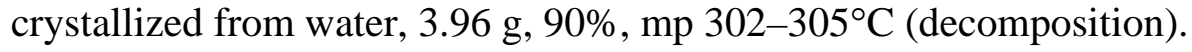

${ }^{1} \mathrm{H},{ }^{13} \mathrm{C}$, and ${ }^{11} \mathrm{~B}$ spectra were identical with the spectra described above.

3-(4-Bromobenzyl)cyclobutanone (19). A solution of trichloroacetyl chloride (16.8 mL, $150 \mathrm{mmol})$ and phosphorous oxychloride $(14.0 \mathrm{~mL}, 150 \mathrm{mmol})$ in diethyl ether $(70 \mathrm{~mL})$ was added dropwise with stirring in $1 \mathrm{~h}$ to a mixture of $\mathbf{6}$ and 7 (22.91 g, $100 \mathrm{mmol}$ of 6), freshly prepared Cu-Zn couple ${ }^{29}$ (13.10 g, $200 \mathrm{mmol}$ ), and diethyl ether $(150 \mathrm{~mL})$, under nitrogen atmosphere. The reaction mixture was stirred for $1 \mathrm{~h}$ at room temperature and then refluxed for $3 \mathrm{~h}$. After cooling to room temperature it was filtered through a cellite pad which was then washed with diethyl ether $(100 \mathrm{~mL})$. The filtrate was washed with ice-water $(50 \mathrm{~mL})$, neutralized with saturated sodium bicarbonate solution $(3 \times 50 \mathrm{~mL})$, washed with water $(3 \times 30 \mathrm{~mL})$, saturated brine $(30 \mathrm{~mL})$, and dried with magnesium sulfate. Ether was removed and a brown liquid which was obtained was dissolved in acetic acid (35 mL). Zinc powder (13.07 g, $200 \mathrm{mmol}$ ) was added, and the mixture was stirred at room temperature for $30 \mathrm{~min}$, and then was gently refluxed for $2 \mathrm{~h}$. After cooling to room temperature it was filtered through a cellite pad which was washed with ethyl acetate $(100 \mathrm{~mL})$. The filtrate was concentrated under vacuum to remove most of acetic acid. Ethyl acetate $(30 \mathrm{~mL})$ was added, and the solution was washed with saturated sodium bicarbonate solution $(25 \mathrm{~mL})$, water $(25 \mathrm{~mL})$, saturated brine $(25 \mathrm{~mL})$, and 
dried with magnesium sulfate. The product was isolated by distillation, $12.34 \mathrm{~g}$, 52\%, bp $140-142^{\circ} \mathrm{C} / 2 \mathrm{mmHg}, \mathrm{n}_{\mathrm{D}}^{20}=1.5462$.

Anal. Calcd. for $\mathrm{C}_{11} \mathrm{H}_{11} \mathrm{BrO}$ (239.11): C, 55.25; H, 4.64. Found: C, 56.02; H, 4.65.

NMR data: $\delta_{\mathrm{H}}\left(200 \mathrm{MHz}, \mathrm{CDCl}_{3}\right) 2.70$ (septet, J = 6.8 Hz, 1H, CH), $2.84\left(\mathrm{~m}, 4 \mathrm{H}, \mathrm{CH}_{2}\right), 3.12(\mathrm{~m}$, $\left.2 \mathrm{H}, \mathrm{CH}_{2}\right), 7.06$ and $7.42\left(4 \mathrm{H}\right.$, an $\mathrm{AA}^{\prime} \mathrm{XX}$ ' system characteristic for para disubstituted benzene). $\delta_{\mathrm{C}}\left(\mathrm{CDCl}_{3}\right) 24.82(\mathrm{CH}), 41.18\left(\mathrm{CH}_{2}\right), 52.19\left(\mathrm{CH}_{2}\right), 120.19(\mathrm{C}), 130.18(2 \times \mathrm{CH}), 131.63(2 \times$ $\mathrm{CH}), 138.89(\mathrm{C}), 206.93(\mathrm{C}=\mathrm{O})$.

IR (film) $\mathrm{cm}^{-1}: 1770$ (sb, C=O), $1480\left(\mathrm{~s}, \mathrm{C}=\mathrm{C}_{\mathrm{Ar}}\right), 830\left(\mathrm{~m}, \mathrm{CH}_{\mathrm{Ar}}\right)$.

3-(4-Bromobenzyl)cyclobutanone ethylene ketal (20). A mixture of 19 (5.98 g, $25.0 \mathrm{mmol})$, ethylene glycol (6.20 mL, $100 \mathrm{mmol}), p$-toluenesulfonic acid (0.25 g, $1.33 \mathrm{mmol})$ and benzene (85 mL) was refluxed for $22 \mathrm{~h}$ with a Dean-Stark trap. The mixture was cooled, washed with 3M sodium hydroxide $(5 \mathrm{~mL})$, water $(20 \mathrm{~mL})$, saturated brine $(20 \mathrm{~mL})$, and dried with magnesium sulfate. Benzene was removed under vacuum and the product was isolated by crystallization from $n$-pentane, $6.11 \mathrm{~g}, 86 \%$, mp $50-52^{\circ} \mathrm{C}$.

Anal. Calcd. for $\mathrm{C}_{13} \mathrm{H}_{15} \mathrm{BrO}_{2}$ (283.16): C, 55.14; H, 5.34. Found: C, 55.18; H, 5.50.

NMR data: $\delta_{\mathrm{H}}\left(500 \mathrm{MHz}, \mathrm{CDCl}_{3}\right) 2.00\left(\mathrm{~m}, 2 \mathrm{H}, \mathrm{CH}_{2}\right), 2.28$ (septet, $\left.J=7.5 \mathrm{~Hz}, 1 \mathrm{H}, \mathrm{CH}\right), 2.37(\mathrm{~m}$, 2H, $\mathrm{CH}_{2}$ ), 2.69 (d, $J=7.5 \mathrm{~Hz}, 2 \mathrm{H}, \mathrm{CH}_{2}$ ), 3.84 (s, 4H, $\mathrm{CH}_{2}$ ), 6.99 (d, $\left.J=8.5 \mathrm{~Hz}, 2 \mathrm{H}, \mathrm{H}_{\mathrm{Ar}}\right), 7.35$ $\left(\mathrm{d}, J=8.5 \mathrm{~Hz}, 2 \mathrm{H}, \mathrm{H}_{\mathrm{Ar}}\right) . \delta_{\mathrm{C}}\left(\mathrm{CDCl}_{3}\right) 26.06(\mathrm{CH}), 40.81\left(2 \times \mathrm{CH}_{2}\right), 41.46\left(\mathrm{CH}_{2}\right), 63.54\left(\mathrm{CH}_{2}\right)$, $63.97\left(\mathrm{CH}_{2}\right), 106.40(\mathrm{C}), 119.66(\mathrm{C}), 130.21(2 \times \mathrm{CH}), 131.33(2 \times \mathrm{CH}), 139.70(\mathrm{C})$.

3-(4-Dihydroxyborylbenzyl)cyclobutanone (21). A solution of 20 (2.83 g, $10.0 \mathrm{mmol}$ ) in tetrahydrofuran $(40 \mathrm{~mL})$ was cooled to $-78^{\circ} \mathrm{C}$, and $2.5 \mathrm{M} n$-butyllithium solution in hexanes $(4.4 \mathrm{~mL}$, $11.0 \mathrm{mmol}$ ) was added dropwise under argon atmosphere. The mixture was stirred at $-78^{\circ} \mathrm{C}$ for 1 h, triisopropoxyborane $(2.07 \mathrm{~mL}, 11.0 \mathrm{mmol})$ was added, and stirring was continued overnight at room temperature. After cooling to $0^{\circ} \mathrm{C}, 2 \mathrm{M}$ hydrochloric acid $(11.0 \mathrm{~mL}, 22 \mathrm{mmol})$ was added and the mixture was stirred for $10 \mathrm{~h}$ at room temperature. The organic layer was separated and the aqueous layer was extracted with diethyl ether $(20 \mathrm{~mL})$. The combined organic solution was washed with saturated brine $(20 \mathrm{~mL})$ and dried with magnesium sulfate. Solvents were removed under vacuum and the product was isolated by crystallization from ethanol-water (1:1), $1.80 \mathrm{~g}$, $88 \%$, mp $162-165^{\circ} \mathrm{C}$.

NMR data: $\delta_{\mathrm{H}}(200 \mathrm{MHz}, \mathrm{DMSO}) 2.65(\mathrm{~m}, 1 \mathrm{H}, \mathrm{CH}), 2.83\left(\mathrm{~m}, 4 \mathrm{H}, \mathrm{CH}_{2}\right), 3.05\left(\mathrm{~m}, 2 \mathrm{H}, \mathrm{CH}_{2}\right), 7.18$ (d, $\left.J=8.0 \mathrm{~Hz}, 2 \mathrm{H}, \mathrm{H}_{\mathrm{Ar}}\right), 7.69\left(\mathrm{~d}, J=8.0 \mathrm{~Hz}, 2 \mathrm{H}, \mathrm{H}_{\mathrm{Ar}}\right) . \delta_{\mathrm{C}}(\mathrm{DMSO}) 24.48(\mathrm{CH}), 41.02\left(\mathrm{CH}_{2}\right)$, $51.75\left(2 \times \mathrm{CH}_{2}\right), 127.61(2 \times \mathrm{CH}), 134.24(2 \times \mathrm{CH}), 142.41(\mathrm{C}), 207.69(\mathrm{C}=\mathrm{O}) . \delta_{\mathrm{B}}(\mathrm{AcOEt})$ 31.82 .

IR (KBr) cm ${ }^{-1}$ : 3397 (sb, OH), 1766 (s, C=O), 1610 (m, $\mathrm{CH}_{\mathrm{Ar}}$ ), 1342 (sb, B-O), 838 (mb, $\mathrm{CH}_{\mathrm{Ar}}$ ). 3-(4-Dihydroxyborylbenzyl)cyclobutanone hydantoin (22). A mixture of 21 (2.04 g, 10.0 mmol), 30\% ethanol (20.0 mL), potassium cyanide (1.30 g, $20.0 \mathrm{mmol})$, and ammonium carbonate (4.80 g, $50.0 \mathrm{mmol}$ ), was placed in an autoclave and kept at $60^{\circ} \mathrm{C}$ for $4 \mathrm{~h}$. After cooling, the mixture was acidified with $4 \mathrm{M}$ hydrochloric acid. Ethanol and water were removed under vacuum and the product was crystallized from ethanol-water (1:20), $1.30 \mathrm{~g}, 95 \%$, mp $256-258^{\circ} \mathrm{C}$. 
Anal. Calcd. for $\mathrm{C}_{13} \mathrm{H}_{15} \mathrm{BN}_{2} \mathrm{O}_{4} \cdot \mathrm{H}_{2} \mathrm{O}$ (292.11): C, 53.45; H, 5.87; N, 9.59. Found: C, 53.52; H, 5.90; N, 9.60.

NMR data of the major diastereomer: $\delta_{\mathrm{H}}(300 \mathrm{MHz}, \mathrm{DMSO}) 1.97(\mathrm{~m}, 2 \mathrm{H}, \mathrm{CH}), 2.20(\mathrm{~m}, 2 \mathrm{H}$, $\mathrm{CH}_{2}$ ), 2.39 (m, 1H, $\mathrm{CH}_{2}$ ), 2.66 (d, $\left.J=6.9 \mathrm{~Hz}, 2 \mathrm{H}, \mathrm{CH}_{2}\right), 7.11$ (d, $\left.J=8.1 \mathrm{~Hz}, 2 \mathrm{H}, \mathrm{H}_{\mathrm{Ar}}\right), 7.69$ (d, $J$ $\left.=8.1 \mathrm{~Hz}, 2 \mathrm{H}, \mathrm{H}_{\mathrm{Ar}}\right), 7.98(\mathrm{~s}, 2 \mathrm{H}, \mathrm{OH}), 8.23(\mathrm{~s}, 1 \mathrm{H}, \mathrm{NH}), 10.55$ (s, 1H, NH). $\delta_{\mathrm{C}}(\mathrm{DMSO}) 27.74$ $(\mathrm{CH}), 36.83\left(\mathrm{CH}_{2}\right), 38.11\left(\mathrm{CH}_{2}\right), 42.36\left(\mathrm{CH}_{2}\right), 57.76(\mathrm{C}), 127.45(2 \times \mathrm{CH}), 134.29(2 \times \mathrm{CH})$, $141.84(\mathrm{C}), 155.98(\mathrm{C}=\mathrm{O}), 178.73(\mathrm{C}=\mathrm{O})$.

IR (KBr) cm ${ }^{-1}$ : 3311 (sb, OH), 2934 (m, CH), 1721 (s, C=O), 1610 (m, CH $\mathrm{Ar}_{\mathrm{Ar}}$, 1359 (sb, B-O), 1125 (m, C-O), $767\left(\mathrm{mb}, \mathrm{CH}_{\mathrm{Ar}}\right)$.

1-Amino-3-(4-dihydroxyborylbenzyl)cyclobutanecarboxylic acid (4). To a degassed 2M sodium hydroxide solution (11.8 mL, $23.6 \mathrm{mmol}$ ) was added 22 (1.10 g, $4.02 \mathrm{mmol})$ and the mixture was refluxed for $2 \mathrm{~h}$ under nitrogen atmosphere. TLC analysis indicated no hydantoin. Activated carbon ( $0.52 \mathrm{~g}$ ) was added and the mixture was filtered. The filtrate was neutralized with $6 \mathrm{M}$ hydrochloric acid. The precipitate which was formed was filtered off and crystallized from ethanol-water, $0.54 \mathrm{~g}, 54 \%$, $\mathrm{mp} 280-282^{\circ} \mathrm{C}$ (decomposition).

NMR data of the major diastereomer: $\delta_{\mathrm{H}}\left(300 \mathrm{MHz}, \mathrm{D}_{2} \mathrm{O}, \mathrm{DCl}, \mathrm{CD}_{3} \mathrm{OD}\right) 1.69\left(\mathrm{~m}, 2 \mathrm{H}, \mathrm{CH}_{2}\right), 2.4$ (m, 3H, $\mathrm{CHCH}_{2}$ ), 2.55 (m, 2H, $\mathrm{CH}_{2}$ ), 7.24 (d, $\left.J=7.8 \mathrm{~Hz}, 2 \mathrm{H}, \mathrm{H}_{\mathrm{Ar}}\right), 7.68$ (d, $J=7.8 \mathrm{~Hz}, 2 \mathrm{H}, \mathrm{H}_{\mathrm{Ar}}$ ) $\delta_{\mathrm{C}}\left(\mathrm{CD}_{3} \mathrm{OD}\right) 29.22(\mathrm{CH}), 38.11\left(2 \times \mathrm{CH}_{2}\right), 42.06\left(\mathrm{CH}_{2}\right), 59.85(\mathrm{C}), 128.86(2 \times \mathrm{CH}), 135.11$ $(2 \times \mathrm{CH}), 146.85(\mathrm{C}), 179.82(\mathrm{C}=\mathrm{O}) . \delta_{\mathrm{B}}\left(\mathrm{CD}_{3} \mathrm{OD}\right) 23.55$.

\section{Acknowledgements}

Financial support from the Committee of Scientific Research, Warsaw, grant 6P05F 02320p03 is acknowledged.

\section{References}

1. Soloway, A. H.; Tjarks, W.; Barnum, B. A.; Rong, F.-G.; Barth, R. F.; Codogni, I. M.; Wilson, J. G. Chem. Rev. 1998, 98, 1515.

2. Hawthorne, M. F. Angew. Chem., Int. Ed. 1993, 32, 950.

3. Hawthorne, M. F.; Maderra, A. Chem. Rev. 1999, 99, 3421.

4. Sauerwein, W.; Zurlo A. European J. Cancer. 2002, 38, S31.

5. Boron Neutron Capture Therapy for Tumors, Hatanaka H. Ed., Niigata: Nishimura, 1986.

6. Cancer Neutron Capture Therapy; Mishima, Y. Ed.; Plenum Press: New York, 1996.

7. Coderre, J. A.; Elowitz, E. H.; Chadha, M.; Bergland, R.; Capala, J.; Joel, D. D.; Liu, H. B.; Slatkin, D. N.; Chanana, A. D. J. Neuro-Oncology 1997, 33, 141.

8. Lesnikowski, Z. J.; Shi, J.; Schinazi, R. F. J. Organomet. Chem. 1999, 581, 156. 
9. Martin, B.; Posseme, F.; Le Barbier, C.; Carreaoux, F.; Carboni, B.; Seiler, N.; Moulinoux, J.-P.; Delcros, J.-G. Bioorg. Med. Chem. 2002, 10, 2863.

10. Ghaneolhosseini, H.; Tjarks, W.; Sjoberg, S. Tetrahedron 1998, 54, 3877.

11. Nakamura, H.; Fujiwara, M.; Yamamoto, Y. Bull. Chem. Soc. Japan 2000, 73, 231.

12. Malan, Ch.; Morin, Ch. J. Org. Chem. 1998, 63, 8019.

13. Jung, E.; Lazarova, T. I. J. Org. Chem. 1999, 64, 2976.

14. Park, K. C.; Yoshino, K.; Tomiyasu, H. Synthesis 1999, 2041.

15. Masunaga, S.-I.; Ono, K.; Kirihata, M.; Takagaki, M.; Sakurai, Y.; Kinashi, Y.; Kobayashi, T.; Nagasawa, H.; Uto, Y.; Hori, H. Japn. J. Cancer Res. 2001, 92, 996.

16. Takagaki, M.; Powell, W.; Sood, A.; Spielvogel, B. F.; Hosmane, N. S.; Kirihata, M.; Ono, K.; Masunaga, S.-I.; Kinashi, Y.; Miyatake, S.-I.; Hashimoto, N. Radiation Res. 2001, 156, 118.

17. Srivastava, R. R.; Singhaus, R. R.; Kabalka, G. W. J. Org. Chem. 1999, 64, 8495.

18. Srivastava, R. R.; Kabalka, G. W. J. Org. Chem. 1997, 62, 8730.

19. Srivastava, R. R.; Singhaus, R. R.; Kabalka, G. W. J. Org. Chem. 1997, 62, 4476.

20. Kabalka, G. W.; Das, B. C.; Das, S. Tetrahedron Lett. 2001, 42, 7145.

21. Das, B. C.; Das, S.; Li, G.; Bao, W.; Kabalka, G. W. Synlett 2001, 1419.

22. Huber, K. S.; Thie, J. A.; Smith, G. T.; Kabalka,G. W. ; Keller, I. B.; Cliefoth, A. B.; Campbell, S. K.; Buonocore E. Clin. Positron Imaging 1998, 1, 165.

23. O'Donnell, M. J.; Bennett, W. D.; Bruder, W. A.; Jacobsen, W.N.; Knuth, K.; LeClef, B.; Polt, R. L.; Bordwell, F. C.; Mrozack, S. R.; Cripe, T. A. J. Am. Chem. Soc. 1988, 110, 8520.

24. Mashchenko, N. V.; Matveeva, A. G.; Odinets, I. L.; Matrosov, E. I.; Petrov, E. S.; Terekhova, M. I.; Matveev, A. K.; Mastrjukova, T. A.; Kabachnik, M. I. Zh. Obshch. Khim. 1988, 58, 1973.

25. Jones, L. B.; Foster, J. P. J. Org. Chem. 1970, 35, 1777.

26. Kaminski, J. J.; Lyle, R. E. Org. Mass Spectrom. 1978, 13, 425.

27. Bays, D. E.; Foster, R. V. US Pat. 3647 881; Chem. Abstr. 1970, 73, 66268.

28. Inaba, S.; Rieke, R. D. J. Org. Chem. 1985, 50, 1373.

29. Krepski, L. R.; Hassner, A. J. Org. Chem. 1978, 43, 2879. 